\title{
ANALISIS KEBIJAKAN PENGENDALIAN INFLASI DKI JAKARTA
}

\author{
H. Yurianto
}

Universitas Prof Dr. HAMKA Jakarta

\begin{abstract}
Jakarta's role in the national economy is very central. Contributions economy Jakarta nationwide reach 16 to 17 percent of total national GDP. Indicators of inflation is very central.Inflation is low and stable would be a stimulator of economic growth. This study aims to: a) discuss the development of the inflation rate in Jakarta, b) discuss and analyze the policy of inflation control in Jakarta and c) comparing the calculation of the inflation rate to the inflation rate in 2017-2022 RPJMD. The study used a qualitative descriptive approach. In conclusion Regional Inflation Control Team (TPID) Jakarta to be very central in controlling inflation. BUMD, the food cluster was instrumental and constructive in terms of the provision of some major food commodities. The rate of inflation and economic growth RPJMD and Simultaneous Equation Model shows that there are differences in nominal figures. But in the nominal rate projections for both relatively stable and the same. Policy strategy of the four K (4 K), namely affordability, availability of supplies, smoothness distribution and communications has given excellent results and is conducive to the economy of Jakarta. The Jakarta Provincial Government cooperation with the regions and between enterprises working with other regions Jakarta quite effective.bazaar and market operations are to periodically shown to be effective in controlling inflation. So it is necessary to continue.
\end{abstract}

\section{Kata kunci :kebijakan, inflasi, jakarta \\ Korespondensi $\quad$ :yurimerdeka@gmail.com}

\section{PENDAHULUAN}

Jakarta mempunyai peran yang sangat penting dalam perekonomian Nasionoal. Kontribusi perekonomian Jakarta dalam lingkup nasional mencapai 16- 17 Persen dari total PDB nasional. Sumbangan ini merupakan sumbangan tertinggi dibanding kontirbusi daerah provisni lain. Dengan demikian maka dinamika dan pergerakan perekonomian Nasional sangat dipengaruhi oleh perekonomian Jakarta.

Indikator inflasi merupakan salah satu indikator penting dalam pembangunan ekonomi. Tinggi rendahnya angka inflasi sangat mempengaruhi pola konsumsi, pola distribusi dan pola produksi dalam perekonomian. Angka inflasi yang rendah dapat melesukan perekonomian karena para pelaku usaha tidak bergairah untuk melakukan usahanya. Jika hal ini terjadi tentu akan mengakibatkan perekonomian lesu perekonomian tidak tumbuh jika hal ini terus terjadi tidak menutup kemungkinan perekonomian stagnan.

Terjadi sebaliknya, jika inflasi terlalu tinggi, maka daya beli masyarakat akan melemah. Walaupun para pengusaha bergairah unutk melakukan usahanya tetapi daya beli masyarakat menurun. Pendapatan masyarakat menjadi tidak berharga lagi 
karena harga barang dan jasa terus meningkat. Tentu inflasi yang tinggi juga tidak kondusif bagi perekonomian. Dengan kata lain, laju inflasi yang rendah dan stabil akan menjadi stimulator pertumbuhan ekonom (Sutawijaya dan Zulfahmi, 2012) Zulfahmi. Jadi dengan demikian, muncul pertanyaan berapa angka inflasi yang bagus dnn optimal untuk perekonomian. Hal ini lah yang perlu mendapat perhatian khusus bagi para pengambil kebijakan perekonomian.

Secara analog, bahwa inflasi seperti tekanan darah. Tekanan darah ini jika terlalu tinggi sangat berbahaya dan jika terlalu rendah tidak bagus. Dengan dasar ini, secara implisit bahwa inflasi sangat penting dalam pembangunan ekonomi. Inflasi yang tidak stabil akan mempersulit dunia usaha dalam perencanaan bisnis baik dalam kegiatan produksi, investasi, maupun kegiatan penentuan harga barang dan jasa yang diproduksinya. Untuk itu prediksi laju inflasi menjadi sangat sentral dan penting dalam perekonomian (Suparti, 2013). Dengan kata lain inflasi harus dikelola dengan baik dan dengan professional agar angka inflasi pada tingkatan yang optimal sehingga perekonomian daerah dapat berjalan dengan baik.

Undang undang No 3 tahun 2004 pada pasal 7 mengamanatkan bahwa tugas Bank Indonesia adalah mencapai dan menjaga kestabilan nilai Rupiah, yang salah satunya adalah dalam bentuk kestabilan nilai Rupiah terhadap barang dan jasa yang tercermin melalui kestabilan inflasi. Jadi ini argumen penting juga bahwa inflasi perlu dikendalikan. Dalam hal Bank Indonesia mempunyai tugas untuk menjaga stabilitas nilai rupiah terhadap barang dan jasa. Untuk itu, setiap perwakilan Bank Indonesia di daerah bersama dengan instansi terkait membentuk lembaga pengendali inflasi, yaitu Tim Pengendali Inflasi Daerah ( TPID).

Berdasarkan penelitian(Hidayati Fatimah, 2013),bahwa pembentukan Tim Pengendali Inflasi Daerah (TPID) telah memberikan pengaruh yang baik bagi persistensi inflasi Jawa Timur. Dengan adanya TPID, persistensi inflasi Jawa Timur cenderung mengalami penurunan. Ini menunjukkan bahwa TPID mempunyai peran yang penting dalam perekonomian daerah. Selain itu, penelitian ini juga merekomendasikan bahwa TPID perlu melakukan kerjasama yang koordinatif dengan instansi terkait guna mendukung usaha stabilitas inflasi daerah.

Berkaitan dengan hal ini, inflasi menjadi salah satu subyek menarik dalam dunia akademis. Hasil penelitian Suparti (2013) dengan menggunakan analisis Model Regresi Spline bahwa prediksi laju inflasi yang ditetapkan oleh Pemerintah sebesar 4,5 +/- 1 $\%$ untuk tahun 2012 dapat tercapai namun untuk tahun 2013 laju inflasi sebesar 4,5 +/$1 \%$ tidak dapat tercapai. Ini artinya bahwa prediksi dengan menggunakan suatu model penting tetapi ketepatan dan akurasinya perlu dicermati lebih lanjut.

Secara konsep tingkat inflasi merupakan indikator perekonomian multi dimensi. Penyebab dari inflasi sangat bervariasi. Inflasi dapat disebabkan karena adanya tekanan dari sisi supply (cost push inflation), dan dari sisi permintaan (demand pull inflation), dan dari ekspektasi inflasi.

Berdasarkan hasil penelitian Kardita, Setiawina, dan Budiasa (2018) bahwa inflasi dan pertumbuhan ekonomi di Bali berpengaruh positif terhadap ketimpangan pendapatan masyarakat Bali. Ini mengandung arti bahwa usaha mendorong ekonomi untuk tumbuh itu suatu kewajiban tetapi laju inflasi harus dikelola dengan baik agar pada tingkatan yang optimal. Dengan demikian 
prediksi laju inflasi menjadi penting untuk disusun.

Konsep inflasi adalah konsep multiaspek. Beberapa peneliti telah melakukan penelitian tentang hubungan inflasi dengan pasar uang. Menurut(Wahyudi, Asdar, \& Nohong, 2017) dalam kontek ini menemukan bahwa hubungan antara laju inflasi dengan Indek Harga Saham Gabungan (IHSG) hubungannya negative dan tidak signifikan. Tentu hal ini mengandung arti bahwa pasar uang mempunyai hubungan yang unik dengan laju inflasi. Dalam hal ini, penyusun kebijakan paling memperoleh info bahwa untuk mitigasi inflasi bisa menggunakan indikator pasar uang dalam hal ini adalah menggunakan IHSG.

Mengingat arti pentingnya angka inflasi maka perlu dilakukan pengelolaan angka inflasi yang komprehensif dan profesional. Langkah penting dalam hal ini antara lain adalah identifkasi faktor penyebab, identifikasi kebijakan pengendalian inflasi, penyusunan solusi kebijakan yang konstruktif.

Mendasarkan pada kondisi di atas, maka kajian ini bertujuan untuk:

a. membahas perkembangan laju inflasi di Jakarta,

b. membahas dan menganalisis kebijakan pengendalian inflasi di Jakarta

c. membandingkan perhitungan angka inflasi dengan laju inflasi pada RPJMD 2017-2022

Hasil penelitian ini diharapkan dapat menjadi salah satu masukan untuk penyusunan perencanaan pembangunan daerah terutama berkaitan dengan pembangunan perekonomian Jakarta secara keseluruhan.

\section{METODE PENELITIAN}

Agar hasil yang diperoleh lebih tepat dan menjawab pertanyaan penelitian maka metode penelitian dalam hal ini dibagi menjadi dua, yaitu metode deskriptif kualitatif. Analisis deskriptif-kualitatif dalam penelitian ini digunakan untuk menggambarkan dan menginterpretasikan objek sesuai kondisi obyektif di lapangan. Maksud analisis ini adalah menggambarkan secara sistematis fakta dan karakteristik objek atau subjek yang diteliti secara tepat. Di samping itu, analisis deskriptif digunakan untuk menjelaskan kebijakan yang berkaitan dengan keadaan dan kejadian sekarang. Dengan demikian, hasil analisis deskriptif diharapkan mempunyai validitas yang universal.

Dalam hal ini juga digunakan analisis komparatif-kualitatif. Analisis ini digunakan juga dengan pendekatan kualitatif. Pengertian komparatif dalam hal ini adalah bersifat perbandingan. Jadi tujuannya adalah membandingkan dua fakta dan sifat-sifat objek yang di teliti berdasarkan kerangka pemikiran. Dalam hal ini membandingkan hasil ramalan yang dihitung dengan metode kuantitatif dengan angka proyeksi pada dokumen RPJMD 2017- 2022.

Berkaitan dengan data, pengumpulan data dilakukan dengan mengindetifikas referensi yang akuntabel dan bersesuaian. Data yang digunakan dalam kajian ini adalah data sekunder series untuk periode tahun 1987-2017. Sumber data adalah Badan Pusat Statistik (BPS) Provinsi DKI Jakarta, Kementerian Keuangan, Media Massa baik elektronik maupun non-elektronik, SKPD/UKPD yang ada di lingkungan pemerintah Provinsi DKI Jakarta, dan Bank Indonesia. 


\section{HASIL PENELITIAN}

\section{A. Konsep Inflasi}

Secara konsep bahwa angka inflasi adalah angka yang menunjukkan kecenderungan kenaikan harga barang dan jasa di suatu wilayah. Dalam hal ini bukan berarti bahwa semua harga barang meningkat tetapi bisa saja barang tertentu menurun atau malah tetap tidak menurun.

Kenaikan harga barang dan jasa dapat disebabkan oleh dua hal yaitu apakah permintaan meningkat dan supply tetap atau menurun atau sebaliknya supply nya menurun permintaan tetap atau menurun. Menurut BPS, bahwa Inflasi pada dasarnya kecenderungan naiknya harga barang dan jasa yang berlangsung dan sifatnya terus menerus. Dengan demikian maka jika harga barang dan jasa di dalam negeri meningkat, maka inflasi mengalami kenaikan. Implikasi lain dari hal ini adalah bahwa naiknya harga barang dan jasa tersebut dapat menyebabkan turunnya nilai uang. Dengan demikian, inflasi dapat juga diartikan sebagai penurunan nilai uang terhadap nilai barang dan jasa secara umum.

Sejalan dengan hal tersebut secara teori ada dua type inflasi yaitu cost- push inflation dan demand-pull inflation. Dalam kasus cost-push inflation, inflasi disebabkan oleh keterbatasan supply atau cost pada pasar. Harga harga naik karena biaya produksi perunit produk juga meningkat. Naiknya biaya produksi menjadikan keunutungan menurun sehingga hal ini menurunkan semangat produsen untuk memenuhi kebutuhan produk pada pasar tersebut dengan harga yang tetap sama. Kondisi ini mengakibatkan jumlah barang yang disupply menurun. Oleh karena itu, dalam hal ini meningkatnya cost mendorong harga produk meningkat sementara demand tidak mampu menyesuaikan hal tersebut.
Selain itu, cost push inflation disebabkan oleh depresiasi nilai tukar, dampak inflasi luar negeri terutama negara-negara partner dagang, peningkatan harga-harga komoditi yang diatur pemerintah (administered price), dan terjadi negative supply shocks akibat bencana alam dan terganggunya distribusi.

Selanjutnya demand-pull inflation pada dasrnya adalah adanya perubahan price level sebagai akibat meningkatnya permintaan total. Perekonomian sebrtulnya tetalah berusahan untuk meneryesuiakan kapasitas produksi. Dalam hal ini para pelaku bisnis tidak mampu merespon dengan cara meningkatkan produksinya karena selurh semua sumber daya dsudah digunakan sepenuhnya, full employed. Peningkatan kelebihan permintaan di atas output yang tersedia hal ini tentu akan meningkatkan harga barang dan jasa. Kondisi ini disebut dengan demand-pull inflation. Hal ini kemungkinan sebagai akibat dari terlalu banyak uang beredar tetapi barang dan jasa yang tersedia terbatas. Dengan kata lain, bahwa demand-pull inflation terjadi jika output riil yang melebihi output potensialnya atau permintaan total (agregate demand) lebih besar dari pada kapasitas perekonomian.

Namun demikian pada kenyataanya bahwa hubungan antara harga, penawaran dan permintaan cukup kompleks. Hubungan ini sangat dipengaruhai oleh berbagai faktor baik faktor ekonomi maupun faktor non ekonomi. Faktor ekonomi antara lain seperti jumlah tenaga kerja, harga faktor produksi lain, selera konsumen, dan kondisi upah tenaga kerja. Sedangkan faktor non ekonomii meliputi faktor politik, budaya, kebiasaan, pendidikan dan social.

Sama seperti di daerah lain, di Jakarta, inflasi juga sangat dipengaruhi oleh beberapa faktor. Peringatan hari besar keagamaan juga 
merupakan momentum penting dalam mempengaruhi tingkat inflasi. Pada hari besar ini walaupun ketersediaan barang diperkirakan cukup unutk mengahdapai permintaan, harga barang dan jasa pada hari raya tersebut tetap mengalami peningkatan dan bisanya lebih tinggi dari kondisi supplydemand normal. Selain hari bersar keagaman peristiwa pembahasan upah minimum provinisi sering para pedagang juga sering ikut pula menaikan harga harga barang walaupun kenaikan upah tersebut kurang signifikan unutk mendorong kenaikan permintaan

Sementara itu, faktor ekspektasi inflasi juga cukup mempengaruhi laju inflasi. Para pelaku usaha sering juga menggunakan ekspektasi angka inflasi dalam keputusan kegiatan ekonominya. Ekspektasi inflasi tersebut apakah lebih cenderung bersifat adaptif atau forward looking. Hal ini tercermin dari perilaku pembentukan harga di tingkat produsen dan pedagang terutama pada saat menjelang hari-hari besar keagamaan seperti Hari Raya Idul fitri , Natal dan tahun, dan tahun baru).

Jadi jelas bahwa tingkat inflasi di suatu daerah sangat unik. Dengan demikian maka tingkat inflasi pada suatu negara atau daerah berbeda antara yang satu dengan daerah lainnya. Hal ini tentu tergantung dari kondisi perekonomian negara atau wilayah masing masing dan juga kebijakan perekonomiannya. Sebagai contoh pada tahun 1990 laju inflasi di Yunani hanya 20 persen. Di Polandia mencapai 586 persen dan Yugoslavia 583 persen. Yang lebih fenomenal lagi adalah negara negeri Amerika Latin dimana angka inflasinya sangat tinggi. Pada tahun 1990 laju inflasi di Brazil mencapai 2938 persen, Argentina 2314 persen dan Peru 7482 persen. Kesemuanya ini sangat tergantung dari supply, demand barang dan jasa, faktorekonomi dan non ekonomi serta kebijakan ekonominya.

Analog dengan contoh di atas, maka angka inflasi di daerah pada dasarnya merupakan hasil dari interaksi aktivitas perekonomian. Dalam kontek DKI Jakarta, pengendalian inflasi melibatkan banyak institusi. Dalam hal ini institusi yang terlibat meliputi Pemerintah Pusat, Pemerintah Daerah, dunia usaha, media massa, dan masyarakat serta konsumen itu sendiri. Oleh karena itu tidak mudah pengeloallan inflasi jika tidak dilakukan secara komprehensif, holistik dan integrati dari seluruh pemangku kepentingan.

Untuk kasus tingkat inflasi di Indoneisia dicatat dan dihitung oleh BPS. Dalam pencataan inflasi di Indonesia, BPS melakukan disagegasi inflasi. Hal ini dilakukan dengan melakukan bahwa IHK tersebut dikelompokan menjadi inflasi inti dan inflasi non inti ( Bank Indonesia, 2019):

a. Yang dimaksud dengan Inflasi Inti, adalah komponen inflasi yang cenderung menetap atau persisten (persistent component) di dalam pergerakan inflasi dan dipengaruhi oleh faktor fundamental, seperti:

Interaksi permintaan-penawaran, Lingkungan eksternal: nilai tukar, harga komoditi internasional, inflasi mitra dagang, Ekspektasi Inflasi dari pedagang dan konsumen

b. Yang dimaksud dengan Inflasi non Inti, yaitu komponen inflasi yang cenderung tinggi volatilitasnya karena dipengaruhi oleh selain faktor fundamental. Komponen inflasi non inti terdiri dari :

Inflasi Komponen Bergejolak (Volatile Food) : Inflasi yang dominan dipengaruhi oleh shocks (kejutan) dalam kelompok bahan makanan seperti panen, gangguan alam, atau faktor 
perkembangan harga komoditas pangan domestik maupun perkembangan harga komoditas pangan internasional.

Inflasi Komponen Harga yang diatur Pemerintah (Administered Prices) : Inflasi yang dominan dipengaruhi oleh shocks (kejutan) berupa kebijakan harga Pemerintah, seperti harga BBM bersubsidi, tarif listrik, tarif angkutan, dll.

Laju inflasi suatu daerah erat kaitannya dengan ketahanan pangan daerah. Hal ini berdasarkan data empiric bahwa penyumbang inflasi di daerah adalah fluktuasi harga pangan. Argumennhya adalah bahwa ketahanan pangan diartikan sebagai suatu kondisi terpenuhinya pangan bagi negara sampai dengan perseorangan, yang tercermin dari tersedianya pangan yang cukup, baik jumlah maupun mutunya, aman, beragam, bergizi, merata, dan terjangkau serta tidak bertentangan dengan agama, keyakinan, dan budaya masyarakat, untuk dapat hidup sehat, aktif, dan produktif secara berkelanjutan inflasi ketrahana pengan Peningkatan Ketahanan Pangan ( Undang undang No.18 Tahun 2012 tentang Pangan). Mencermati hal ini maka pengendalian inflasi berkaitan erat dengan kebijakan program ketahanan pangan.

Dari sisi moneter, inflasi didekati dengan jumlah uang beredar dalam hal ini mengemuka Teori Kuantitas. Teori ini membahas tentang inflasi, dikenal sebagai model kaum moneteris (monetarist models). Inti dari teori ini adalah sebagai berikut(Bradley, McMullen, Atmadja, Simiyu, \& Artz, 2011): a) Inflasi hanya bisa terjadi kalau ada penambahan volume uang beredar, baik uang kartal maupun giral. b) Laju inflasi juga ditentukan oleh laju pertambahan jumlah uang beredar dan oleh harapan (ekspektasi) masyarakat mengenai kenaikan harga di masa mendatang. Dengan demikian maka faktor yang mempengaruhi inflasi bukan hanya dari sisi fiscal saja melainkan juga dari sisi moneter, yaitu jumlah uang beredar. Artinya dalam pengendalian inflasi perlu memperhatikan sisi moneter.

\section{B. Kebijakan Pengendalian Inflasi Dki Jakarta}

Inflasi dalam perekonomian daerah merupakan isu penting karena inflasi merupakan indikator utama perekonomian daerah. Indikator ini mencakup berbagai aspek kehidupan. Begitu pentingnnya isu ini maka dalam pembangunan daerah isu ini menjadi prioritas dalam menyusun program dan kegiatan pembangunan daerah. Di Jakarta, berdasarkan RPJMD 2017-2022 disebutkan bahwa terdapat 23 Janji Kerja Kepala Daerah dan Wakil Kepala Daerah yang dimandatkan oleh warga Jakarta yang merupakan unsur pokok dalam menyusun program dan kegiatan pada RPJMD Provinsi DKI Jakarta Tahun 2017-2022. Salah satu janji ini, yaitu janji kelima adalah mengendalikan harga-harga kebutuhan pokok dengan menjaga ketersediaan bahan baku dan menyederhanakan rantai distribusi, menyediakan Kartu Pangan Jakarta untuk meningkatkan daya beli warga tidak mampu, serta merevitalisasi pasar-pasar tradisional dan Pedagang Kali Lima untuk meningkatkan kesejahteraan para pedagang.

Berkaitan dengan hal ini, dalam RPJMD 2017- 2022, disebutkan bahwa Misi Kedua: "Menjadikan Jakarta kota yang memajukan kesejahteraan umum melalui terciptanya lapangan kerja, kestabilan dan keterjangkauan kebutuhan pokok, 
meningkatnya keadilan sosial, percepatan pembangunan infrastruktur, kemudahan investasi dan berbisnis, serta perbaikan pengelolaan tata ruang".

Hal yang penting dalam hal ini yang berkaitan dengan isu inflasi adalah isu memajukan kesejahteraan umum, lapangan kerja, kestabilan dan keterjangkauan kebutuhan pokok, meningkatnya keadilan sosial, kemudahan investasi, dan berbisnis. Secara implisit bahwa isu inflasi sangat berkaitan dengan ketahanan pangan.

Pada misi kedua RPJMD 2017 - 2022, Tujuan yang ketiga adalah mewujudkan ketahanan pangan yang terjangkau, memadai, berkualitas, dan berkelanjutan. Adapun sasarannya tersedianya stok kebutuhan pangan yang terjamin jumlah dan mutunya serta terjangkau bagi masyarakat. Ini menunjukkan bahwa isu ketahanan pangan sangat strategis dalam pembangunan perekonomian DKI Jakarta.

Berkaitan dengan pembangunan daerah, isu strategis yang berkaitan dengan perekonomian Jakarta untuk periode 20172022 adalah isu penguatan katahanan pangan, isu indsustri kreatif dan berdaya asing, isu pengurangan ketimpangan ekonomi dan perluasan kesempatan kerja, isu ketahanan energi isu pengembangan system transportasi.

Isu ketahanan pangan pada pembangunan daerah periode 2017-2022 ini adalah isu ketergantungan DKI Jakarta dari daerah atas pangan mencapai $95 \%$. Isu yang lain adalah bahwa inflasi volatile food merupakan penyumbang inflasi daerah yang terbesar. Hal ini disebabkan oleh jalur distribusi yang kurang efektif dan sering mengalami hambatan, rantai distribusi pangan utama biasanya panjang, dan ketersediaan pasokan pangan tidak menentu, kurangnya infrastruktur logistic, kurangnya moda trasnportasi, tidak adanya Gudang yang unutk menyimpan dan dekat dengan warga , dan kesehatan pangan yang masih perlu perhatian khusus. Dalam kontek ini, isu penguatan ketahanan pangan adalah ketersediaan ,kerterjangkauan, dan kesehatan pangan. Salah satu perspektif penting dalam hal ini adalah pengendalian inflasi daerah

Kemudian dalam mewujudkan ketahanan pangan di DKI Jakarta diperlukan penguatan kelembagaan dengan mengedapankan aspek ilmu pengetahuan dan teknologi, peningkatan kualitas sumber daya manusia, peningkatan kualitas akses atau keterjangkauan pangan serta peningkatan distribusi dan diversifikasi pangan. Untuk mencapai hal tersebut diperlukan sinergitas antara pemerintah dengan dunia usaha, mendorong BUMD cluster pangan untuk menyediaakn pangan dengan harga pangan pokok terjangkau dan stabil. Kemudian diperlukan optimalisasi kerjasama antar daerah pemasok pangan utama guna memastikan pasokan tetap stabil dan terjaga dengan cara penguatan jalur distribusi pangan.

Kebijakan ketahanan pangan RPJMD 2017 - 2022 bertujuan mewujudkan ketahanan pangan yang terjangkau memadai, berkualitas, dan berkelanjutan. Sementara sasarananya adalah tersedianya stok kebuthhan pangan yang terjamin jumlah dan mutunya serta terjangkau bagi masyrakat. Strateginya adalah ketahanan pangan yang berkelnajutan.

Program ketahanan pangan DKI Jakarta pada periode 2017-2022 bertujuan a)menjamin ketersediaan pangan dalam jumlah dan mutu sesuai standar sepanjang waktu; b) menjamin stabilitas harga pangan strategis supaya dapat diakses oleh setiap individu; c) menjamin akses pangan bagi setiap warga khususnya bagi kelompok berpendapatan rendah dan kelompok khusus 
(lansia, jompo, bayi, ibu hamil); dan d) menjamin status kesehatan setiap penduduk dari bahaya penyakit yang ditimbulkan oleh pangan yang tidak aman atau penyakit yang ditularkan lewat makanan

Selanjutnya bahwa dalam kontek pengendalian inflasi di Jakarta, maka program ketahanan pangan menjadi sangat relevan. Karena berdasarkan data empirik kontributor dominan dan mempengaruhi laju inflasi daerah adalah bahan pangan.

RPJMD 2017- 2022 mengarahkan bahwa Pemerintah Provinsi DKI Jakarta telah melakukan beberapa program dan kegiatan antara lain pengamanan ketersediaan pangan, pengendalian akses, harga, promosi, dan distribusi/ pemasaran untuk pasokan beras, pasokan daging, distribusi ikan, distribusi ayam, distribusi telur dan susu, distribusi sayur dan mayur, buah-buahan dan Skor Pola Pangan Harapan.

Selain itu, dalam hal ketahanan pangan juga telah dilakukan pengawasan pangan dan keamanan pangan. Hal ini dimaksudkan untuk menjaga pangan tetap aman, higienis, bermutu, bergizi, dan tidak bertentangan dengan agama, keyakinan, dan budaya masyarakat.

Agar implementasi kebijakan ketahanan pangan berjalan dengan baik dan konstruktif, telah dilakukan penugasan BUMD kluster pangan. Maksud dari kegiatan ini adalah untuk menjamin ketersediaan pangan juga untuk menjaga stabilisasi harga pangan dan pengendalian inflasi.

Dalam mengimplementasikan kebijakan ini, BUMD melakukan aksi korporasi yang profesional. Aksi korporasi dalam hal meliputi mengendalikan ketersediaan dan kestabilan harga pangan. Dalam hal ini BUMD melakukan usaha pengadaan pangan sendiri baik dengan membangun kawasan sentra produksi pangan di daerah lain, menyewa lahan, kontrak farming, pembelian lahan dan/atau pengajuan hak pakai atau hak guna usaha atas tanah negara.

Selanjutnya dalam hal pengadaan pangan, BUMD melakukan kerja sama dengan melakukan kerja sama dengan Pemerintah Daerah lain dan/atau lembaga dan/atau BUMN/Daerah dan/atau perusahaan swasta dan/atau perorangan berupa pembelian pangan dan/atau pengelolaan Bersama.

Dalam hal distribusi pangan, telah dilakukan keberlanjutan distribusi pangan bersubsidi untuk pemegang KJP dan masyarakat tertentu lainnya. Selanjutnya dalam hal distribusi pangan dilakukan juga pengembangan Kartu Pangan Jakarta; penambahan produk distribusi pangan murah; utilisasi Jak Grosir, Jak Mart, RPTRA, PKK Mart, UMKM.

Dari sisi Supply, BUMD juga telah melakukan optimalisasi pengelolaan sistem pergudangan, antara lain distribution Centre System, Sistem Resi Gudang (SRG) dan Controlled Atmosphere Storage (CAS). Selain itu, dilakukan juga pengembangan perdagangan antar pulau; perintisan kegiatan penggemukan dan pembibitan sapi; pengamanan ketersediaan stok bahan baku ternak dan daging dan pengembangan pusat perkulakan; serta revitalisasi terhadap 28 lokasi pasar tradisional serta membangun Jakgrosir, mini DC rencana di 5 wilayah DKI, dan Jakmart .

Selain itu, dilakkukan juga kerja sama dengan daerah produsen beras untuk memenuhi kebutuhan stok beras bagi DKI Jakarta dan menjaga standby stock beras. Aktivitas ini dilakukan oleh BUMD Kluster pangan yaitu Perumda Pasar Jaya, PT. Food Station Tjipinang Jaya, dan PD Dharma Jaya. Agar semuanya berjalan dengan baik maka 
dilakukan juga pemantauan atas kebutuhan dan suplai pangan secara periodik.

TPID Provinsi DKI Jakarta saat ini tertuang dalam Keputusan Gubernur Nomor 2183 Tahun 2017 tentang Tim Pengendalian Inflasi Daerah dan merupakan penyesuaian atas Keputusan Presiden RI Nomor 23 Tahun 2017 tentang Tim Pengendalian Inflasi Nasional yang mengamanatkan agar dalam struktur susunan TPID Provinsi diketuai oleh Gubernur. Program prioritas TPID Jakarta tetap difokuskan pada pelaksanaan program yang merujuk pada $4 \mathrm{~K}$, yakni ketersediaan pasokan, kelancaran distribusi, komunikasi dan keterjangkauan harga. Roadmap pengendalian inflasi yang telah ditandatangani pada pertengahan tahun 2016, memberikan arahan yang jelas mengenai langkah-langkah konkrit untuk menjaga laju inflasi di DKI Jakarta.

TPID DKI Jakarta memfokuskan pada peningkatan koordinasi antar pemangku kepentingan pengendalian inflasi. Program utamanya adalah upaya pengendalian harga pangan (volatile food) yang menyumbang inflasi cukup besar. Selain itu, focus yang cukup penting adalah pengendalin harga pangan kelompok administered prices dan kelompok inti. Hal ini sejalan dengan kebijakan Pemerintah Pusat faktor yang mampu mempengaruhi tingkat inflasi adalah harga komoditi kebutuhan pangan masyarakat.

Dalam hal perdagangan antar daerah, untuk periode 2017-2022 dalam upaya menghadapi permasalahan perdagangan antar daerah dimaksud dilakukan sistem lelang. Argumennya adalah bahwa sistim ini mampu berperan sebagai media yang dapat mempertemukan berbagai kepentingan pembeli dan penjual, petani terutama dalam pembentukan tingkat harga komoditas.
Dalam pengendalian inflasi di DKI Jakarta , BUMD juga memberikan dukungan yang konstruktif dan mempunyai peran penting dan strategis. Dalam hal ini, ada 3 BUMD kluster pangan uang ikut akitf dalam hal pengendalian inflasi. Keitiga BUMD tersetbu adalah Perumda Pasar Jaya, PD Dharma Jaya, dan PT. Food Station Tjipinang Jaya. Masing masing BUMD punya peran yang spesifik.

PT Food Station Tjipinang Jaya mempunyai tugas: membangun dan menyelenggarkaan sentra perdagangan bahan makan ppokok makanan. Yang kedua mengadakan dan menyalurkan serta menjaga stabilitas suplai distribusi dan harga bahan pangan pokok. Yang ketiga adalah melakukan danmengelola perdagngan umum kebutuhan bahan pokok beras.

PD Dharma Jaya mempunyai tugas usaha pengembangan pembibitan penggemuan dan penyediaan daging lolkal berdaakan klasifikasi ptotongan daging dan pengelohan turunannya. Yang kedua dalah pelayanan faslilitasi dalam penyewaan saran ternak dan turunannya pemotongan dan distribusi.

Perumda Pasar Jaya mempunyai tugas melakasanakan pelayanan umum dalam bidang pengelolaan area pasar, membina perdagang pasar dan ikut membantu stabiliasasi harga dan kelancaran distribusi barang dan jasa di pasar.

Pengendalian harga beras merupakan langkah strategis dalam pengedandalian inflasi. Hal Ini karena secara empirits bahwa beras merupaakan bahan pangan pokok. Kenaikan harga beras di pasar biasanya dapat menjadi pendorong inflasi indeks harga konsumen (IHK). Ini mempunyai arati bahwa inflasi akan terdorong naik. Oleh karena itu, untuk pengendalian inflasi diharapkan harus dapat mengendalikan harga beras di pasar. 
Berkaitan dengan harga beras yang merupakan salah satu kunci pengedalian inflasi maka pengendalian harga beras menjdai sangat urgen, penting dan serius. Dalam hal ini maka peran PT Food Stataion Tjipinanag Jaya menjadai sangat strategis mengingat BUMD ini bisnis utamanya adalah pengelolalan pasar beras. Beberapa fungsi strategis PT Food Stataion Tjipinanag Jaya dalam hal pengendalian inflasi Jakarta adalah:

1. Menjamin ketersediaan suplai beras DKI Jakarta dengan tingakat harga yang terjangakau masyarkaat

2. Sebagai instrument pemerintah untuk pengendalian harga beras DKI Jakarta

3. Merupakan pasar beras terbesar di Indonesia

4. Merupakan pusat perdagangan beras antara daerah dan antara pulau

5. Menjadi acuan harga bagai pasar beras nasional

6. Menggambarkan isu beras seca nasional(Adi, 2019).

Dengan merefer pada uraian di atas maka peran BUMD kluster pangan, yaitu Perumda Pasar Jaya, PD Dharma Jaya, PT. Food Station Tjipinang Djaya dalam pengendalian inflasi menjadi sangat penting. BUMD menyumbang peran yang sangat signifikan terutama dalam hal jaminan ketersediaan pasokan pangan di Jakarta. Kenyataanya bahwa bahan pangan adalah penyumbang angka inflasi di Jakarta. Dengan ketersediaaan pasokan yang mencukupi maka diharapkan laju inflasi Jakarta terkelola dengan baik.

\section{Analisis Kebijakan Inflasi Dki Jakarta 2020-2022}

1. Analisis Perkembangan Laju Inflasi di Jakarta,

Dalam perencanaan pembanguan daerah, sejalan dengan Undang undang No 25 tahun 2004 tentang Sistem Perencanaan Pembangunan Nasional, inflasi menjadi salah satu indikator yang digunakan untuk asumsi penyusunan Rencana Kerja Pemerintah Daerah (RKPD). Selain itu, inflasi juga menjadi salah satu indikator yang mendapat perhatian khusus dalam menyusun kebijakan ekonomi makro karena stabilitas perekonomian sangat ditentukan oleh stabilitas inflasi (Suparmoko, 1995). Dengan demikian indikator inflasi menjadi sangat sentral. Untuk itu perhitungannya harus betul betul cermat dan teliti serta metode yang digunakan harus akuntabel.

Pada dasarnya pengendalian inflasi adalah menjaga agar laju inflasi tetap pada laju yang optimal. Artinya tingkat inflasi masih kondusif bagi perekonomian. Para pengusaha masih terus bersemangat untuk melakukan produksi karena masih memperoleh keuntungan. Pihak konsumen juga tetap mempunyai daya beli yang memungkinkan mereka tetap mampu membeli barang yang diproduksi para produsen. Dengan demikian perekonomian tetap berjalan normal dan mekanisme pasar terkelola dengan baik.

Laju inflasi Provinsi DKI Jakarta mengalami fluktuasi. Pada tahu 2017 laju inflasi terkendali pada level 3,72 persen. Apabila dibandingkan dengan inflasi nasional, inflasi Provinsi DKI Jakarta memiliki tren yang hampir sama. Hal tersebut menunjukkan tren kenaikan harga barang di Provinsi DKI Jakarta cukup dapat menggambarkan kenaikan harga barang secara nasional. 
Sejalan dengan hal ini, perekonomian DKI Jakarta meningkat dari 5,85 persen pada tahun 2016 menjadi 6,22 persen pada tahun 2017. Struktur ekonomi Provinsi DKI Jakarta lebih ditunjang oleh sektor perdagangan besar dan eceran; konstruksi; serta industri pengolahan. Penetapan

Secara umum, perkembangan inflasi DKI Jakarta pada periode 2012 - 2018 sangat bervariasi. Hal yang menarik adalah bahwa laju inflasi Jakarta mempunyai kecenderungan yang seirama dengan laju inflasi nasional. Artinya bahwa deviasi perbedaan antara keduanya relative sedikit. Hal yang sama juga terjadi pada laju pertumbuhan ekonomi. Ini dapat digeneralisasikan bahwa perekonomian Jakarta dapat menjadi indikator perkembangan perekonomian Nasional. Untuk itu gambaran laju inflasi dan pertumbuhan ekonomi Jakarta dan nasional ditunjukkan sebagaimana pada Tabel 1.

Tabel 1. Perbandingan Laju Inflasi (persen) dan Pertumbuhan Ekonomi Jakarta dan Indonesia Tahun $2012-2018$

\begin{tabular}{lllll}
\hline Tahun & $\begin{array}{l}\text { Inflasi } \\
\text { Jakarta }\end{array}$ & $\begin{array}{l}\text { Inflasi } \\
\text { Indonesia }\end{array}$ & $\begin{array}{l}\text { Growth } \\
\text { Jakarta }\end{array}$ & $\begin{array}{l}\text { Growth } \\
\text { Indonesia }\end{array}$ \\
\hline 2012 & 4,52 & 4,30 & 6,53 & 6,03 \\
\hline 2013 & 8,00 & 8,38 & 6,07 & 5,56 \\
\hline 2014 & 8,95 & 8,36 & 5,91 & 5,01 \\
\hline 2015 & 3,30 & 3,35 & 5,85 & 4,88 \\
\hline 2016 & 2,37 & 3,02 & 5,85 & 5,02 \\
\hline 2017 & 3,72 & 3,61 & 6,22 & 5,07 \\
\hline 2018 & 3,27 & 3,13 & 6,17 & 5,17 \\
\hline
\end{tabular}

Sumber: BPS, Jakarta Dalam Angka, beberapa tahun penerbitan, RPJMD 2017-2022

Tabel 1 menginformasikan bahwa pada periode 2012 - 2018, laju inflasi Jakarta dan inflasi Indonesia relative bersesuaian. Angka laju inflasi Jakarta dan Indonesia relatiave sama, deviasinya kecil. Sementara dalam hal tingkat laju inflasi pada tahun tertentu lebih besar Jakarta dan pada masa yang lain laju inflasi nasional lebih tinggi dari Jakarta. Namun demikian dapat disimpulkan bahwa laju inflasi Jakarta merupakan refleksi dari laju inflasi Nasional.

Sebagaimana terinci pada Tabel 1 ,bahwa Infllasi Jakarta cenderung mengalami variasi yang tidak terpola. Inflasi Jakarta yang cukup tinggi terjadi pada tahun 2013 dan 2014. Setelahnya sampai tahun 2018, angka inflasi cenderung menurun dan namun angkanya relative rendah. Laju inflasi Jakarta terendah adalah pada tahun 2016, yaitu hanya 2,37 persen. Sementara yang tertinggi terjadi pada tahun 2014, yaitu sebesar 8,95 persen.

Pertumbuhan ekonomi Jakarta juga relative stabil . walaupun cukup bervariasi tetapi angkanya tidak menunjukkan perubahan yang signifikan. Pertumbuhan ekonomi Jakarta tertinggi terjadi pada tahun 2012 , yaitu sebesar 6,53 persen sementara yang terendah terjadi pada tahun 2016, dengan pertumbuhannya sebesar 5,85 persen. Hal yang menarik adalah bahwa jika laju inflasi deviasinya cukup besar yaitu antara 2, 37 persen pada tahun 2016 dan tertinggi 8,95 persen pada tahun 2014 sementara deviasi pertumbuhan ekonomi hanya mencapai 0,88 , yaitu pertumbuhan tertinggi terjadi pada tahun 2012, yaitu sebesar 6,53 persen dan terendah hanya 5,85 persen, yaitu pada tahun 2016.

Temuan yang menarik adalah bahwa di Jakarta tidak terjadi pola arah hubungan yang teratur antara laju inflasi dengan laju pertumbuhan ekonomi. Artinya bahwa pada saat tertentu laju inflasi naik dan laju pertumbuhan ekonomi menurun, pada masa tertentu inflasi menurun tetapi pertumbuhan ekonomi justru naik. Misalnya pada periode tahun 2012 ke 2013 inflasi meningkat sangat tajam yaitu dari angka 4,52 menjadi 8,00 persen sementara pertumbuhan ekonomi justru menurun dari 6,53 persen menjadi 
6,07 persen. Tetapi pada masa yang lain misalnya dari tahun 2013 ke 2014, pada saat ini laju inflasi naik dari 8,00 menjadi 8,95 persen sementara pertumbuhan ekonomi menurun dari 6,07 persen menjadi 5,91 persen, Jadi tidak ada pola hubungan yang jelas dan teratur hubungan antara laju inflasi dengan laju pertumbuhan ekonomi..

Sejalan dengan hubungan inflasi dan pertumbuhan ekonomi Jakarta, hubugan seperti ini juga terjadi pada tingkat nasional. Pada tahun 2012 ke 2013 laju inflasi Indonesia meningkat cukup tajam dari 4,30 persen menjadi 8,38 persen. Sementara pertumbuhan ekonomi naik dari 6,03 persen menjadi 5,56 persen. Di masa yang lain hubungan tersebut berlawanan arah. Pada tahun 2015 ke 2016, Laju inflasi Indoneisa menurun dari 3,35 persern menjadi 3,02 persen sementara pertumbuhan ekonomi justru meningkat dari 4, 88 persen mendjai 5, 02 persen. Ini artinya bahwa tidak terjadi pola yang hubungan yang jelas dan teratur. Tentu hal ini menjadi masukan yang berharga dalam pengelolaan perekonomian di Jakarta.

Dalam hal hubunganya antara Jakrata dan Indonesia, dapat diperoleh informasi bahwa angka inflasi Jakarta dan angka inflasi Indonesia relative sama besarnnya. Hal ini sebagaimana dinyatakan pada RPJMD bahwa perkembangan inflasi Jakarta akan sangat mempengaruhi perkembangan nasional serta menjadi anchor bagi penetapan harga komoditas di daerah (RPJMD 2017-2022).

Ada hal yang menjadi konsen bahwa pada waktu tertentu angka inflasi DKI Jakarta lebih tinggi dibandingkan dengan laju inflasi Indoneisa. Pada tahun 2012 angka inflasi Jakarta mencapat 4,52 persen sementara angka inflasi Indonesia hanya 4,30 persen. Demikian juga pada tahun 2014 laju inflasi DKI Jakarta mencapai 8,95 persen dan laju inflasi Indonesia 8,36 persen.
Selanjutnya laju inflasi pada tahun 2017 bahwa pada thaun ini laju inflasi DKI Jakarta 3,72 persen dan laju infalsi Indonesia 3, 61 persen. Semunya ini menunjukan angka inflasi Jakarta yang lebih tinggi dari angka inflasi Indonesia. Sementara pada saat lain laju inflasi Jakarta lebih rendah dari laju inflasi Indonesia .

Fenomena ini terjadi mungkin disebabakan bahwa pada tahun tertentu, Jakarta mengalami perubahan perekonomian yang cukup siginifikan tahun 2012, 2014 dan tahun 2017. Pada tahun ini laju inflasi Jakarta jauh lebih tinggi dibanding inflasi nasional. Ini mungkin disebabkan bahwa pada tahun 2012 dan tahun 2017 diselenggarakan pemilihan Gubernur DKI Jakarta sementara pada tahun 2014 diselenggarakan pemilihan presiden. Ini mengandung arti bahwa jika terdapat agenda daerah atau agenda nasional yang massif dan besar di Jakarta maka laju inflasi Jakarta akan lebih tinggi dari laju inflasi Nasional. Dengan demikian maka dapat dihipotesiskan bahwa untuk tahun 2019, laju inflasi Jakarta akan lebih tinggi dari laju nasional.

Indikasi yang sama juga ditemukan pada indikator pertumbuhan ekonomi. Artinya bahwa pertumbuhan ekonomi Jakarta akan lebih tinggi dari pertumbuhan ekonomi nasional pada saat di Jakarta diselenggarakan agenda nasional atau regional yang sifat nya massif, besar dan strategis, seperti pemilihan presiden atau pemilihan gubernur.

Pola hubungan antara laju inflasi dan laju pertumbuhan ekonomi Jakarta perlu mendapat perhatian dari para pengambul kebijakan. Demikian juga pola hubungan antara laju inflasi, laju perutmbuhan ekoniomi antara Jakarta dan Indonesia harus dicermati dengan baik. Hal ini tentunya dapat menjadi masukan dalam proyeksi guna kepentingan pembangunan ekonomi dan 
perencanaan pembangunan daerah. Tetapi ada yang berpendapat bahwa memang tidak ada hubungan yang unik antara inflasi dengan pertumbuhan ekonomi di suatu daerah. Seperti hasil penerlitian yang dilakukan di Kabupaten Magelang (Akhmad,2019) bahwa peningkatan atau penurunan tingkat inflasi tidak dipengaruhi oleh peningkatan atau penurunan pertumbuhan ekonomi. Demikian juga sebaliknya, peningkatan atau penurunan tingkat Pertumbuhan Ekonomi tidak dipengaruhi oleh peningkatan atau penurunan tingkat inflasi.

Namun menjadi catatan bahwa pertumbuhan ekonomi dan inflasi Jakarta sangat dipengaruhi perekonomian regional maupun global maka perlu dilakukan antisipasi untuk masa yang akan datang. Hal berkaitan dengan perekonomian global untuk masa mendatang sangat tidak pasti dan beresiko sebagaimana dikemukakan oleh Alfirman (2019). Ketidakpastian global dan risiko global antara lain adalah fluktuasi harga minyak, perubhan iklim, tensi geopolitik, fenomena Brexit, normalisasi kebijakan moneter Amerika Serikat, perang dagang Amerika Serikat dengan China. Semua ini perlu diantisipasi dengan pro aktif agar dampak negatifnya dapat diminimalisir.

\section{Analisis Komparasi Laju Inflasi DKI Jakarta}

Pada analisis ini akan membandingkan antara proyeksi laju inflasi pada RPJMD dengan laju inflasi hasil perhitungan dengan menggunakan Model Persamaan Simultan (MPS). Proyeksi laju inflasi dan pertumbuhan ekonomi pada RPJMD 20172022 sebagaiman pada Tabel 2. Sementara proyeksi hasil perhiutngan teknokratik MPS dirinci sebagaimana pada Tabel 2.
Tabel 2. Proyeksi Laju Inflasi DKI Jakarta 20202022 pada RPJMD 2017-2022 (persen)Laju

\begin{tabular}{|c|c|c|c|c|}
\hline No & Uraian & $\mathbf{2 0 2 0}$ & $\mathbf{2 0 2 1}$ & $\mathbf{2 0 2 2}$ \\
\hline 1 & Inflasi (yoy persen,) & $\mathbf{5 , 2 1}$ & $\mathbf{5 , 3 8}$ & $\mathbf{5 , 5 7}$ \\
\hline 2 & $\begin{array}{c}\text { Pertumbuhan ekonomi } \\
\text { (persen) }\end{array}$ & $\mathbf{7 . 6 8}$ & $\mathbf{7 , 7 5}$ & $\mathbf{7 , 8 2}$ \\
\hline
\end{tabular}

Sumber : BI, Kantor Perwakilan DKI Jakarta, diambil dari RPJMD DKI Jakarta 2017-2022

Berdasarkan pada Tabel 2, bahwa laju inflasi untuk tiga tahun mendatang diperkirakan cukup stabil dan terkenadali dengan baik. Laju inflasi Jakarta diperkirakan paling tinggi terjadi pada tahun 2020 yaitu 3, 6 Persen. Sementara berangsur angsur turun pada tahun 2021 sebesara 3,4 persen dan pada tahun 2022 laju inflasi hanya 3,3. Sementara itu pada periode yang sama pertumbuhan ekonominya terus mengalami kenaikan yang konsisten. Dengan demikian berdasarkan data pada Tabel 2, terjadi pola yang berlawanan artinya jika laju pertumbuhan ekonomi naik diikuti dengan laju inflasi menurun.

Berdasarkan perhitungan, dengan menggunakan MPS dengan kerangka model yang digunakan adalah pendekatan Blok. Dalam hal ini model terdiri dari enam Blok dan masing Blok terdiri dari persamaan struktural dan persamaan identitas. Hasil perhitungan dengan menggunakan Model ini, yaitu Model Dampak Pengeluaran Pemerintah Daerah terhadap Kinerja Perekonomian Daerah DKI Jakarta, diperoleh hasil angka laju inflasi dan pertumbuhan ekonomi periode 2020 - 2022 sebagaimana terinci pada Tabel.2. (Yurianto, 2018), 
Tabel 3. Proyeksi Laju Inflasi DKI Jakarta 20202022 Hasil Perhitungan dengan Model Persamaan Simultan (MPS).

\begin{tabular}{llll}
\hline Uraian & 2020 & 2021 & 2022 \\
\hline $\begin{array}{l}\text { Inflasi (yoy } \\
\text { persen, +/-1 }\end{array}$ & 3,6 & 3,4 & 3,3 \\
$\%$ ) & & & \\
\hline $\begin{array}{l}\text { Pertumbuhan } \\
\text { ekonomi (\%) }\end{array}$ & 6,7 & 6,9 & 7,0 \\
\hline
\end{tabular}

Sumber : Yurianto, 2018, Proyeksi Potensi Fiskal DKI Jakarta 2018-2022 (Kajian Analisis Model Ekonometrika) Jurnal Desentralisasi Fiskal, Ekonomi dan Keuangan Daerah, Edisi 3 Volume III, Mei-Agustus 2018,

Pada Tabel 3 terlihat bahwa angka inflasi hasil proyeksi terus konsisten meningkat. Jika pada tahun 2020 laju inflasi hanya mencapai 5,21 persen pada tahun 2021 mencapai 5,38 persen dan pada tahun 2022 mencapai 5,57 persen. Sementara itu pertumbuhan ekonomi juga sejalan dengan laju inflasi, yakni mengalami peningkatan yang konsisten. Jika pada tahun 2020 pertumbuhan ekonomi mencapai 7,68 persen tahun 2021 mencapai 7,75 persen dan pada tahun 2022 mencapai 7,82 persen. Jadi ternyata hubungan laju inflasi dan laju pertumbuhan ekonomi sejalan. Dengan demikian dapat disimpulkan bahwa laju Inflasi dan laju pertumbuhan ekonomi periode 2020-2022 dengan pedndeaktan MPS mempunyai pola konsisten mengalami peningkatan. Artinya pada saat laju inflasi meningkat maka laju pertumbuhan ekonomi juga meningkat.

Berdasarkan Tabel 2 dan Tabel 3, tampak laju inflasi proyeksi RPJMD lebih rendah dari angka proyeksi dengan Model Persamaan Simultan (MPS). Namun dilihat trennya berlawanan yaitu jika RPJMD cenderung menurun tetapi dengen MPS cenderung meningkat. Yang menarik adalah bahwa laju inflasi tersebut deviasinya relative kecil. Ini menunjukkan bahwa inflasi DKI Jakarta ke depan tidak terdapat lonjakan yang mengkhawatirkan. Laju inflasi masih sangat kondusif bagi perekonomian Jakarta. Hal ini dengan asumsi bahwa kondisi perekonomian dan kondisi non ekonomi stabil dan terkelola dengan baik dan terkontrol.

Dalam hal pertumbuhan ekonomi, proyeksi RPJMD jauh lebih rendah dari perhitungan dengan pendekatan MPS. Namun hal yang menarik dalam hal ini adalah bahwa untuk periode 2020 - 2022 keduanya sebagaimana pada Tabel 2 dan Tabel 3 memprediksikan pertumbuhan ekonomi yang meningkat. Hal ini tentunya dengan asumsi bahwa perekonomian Jakarta dan perekonomian nasional serta perekonomian global juga stabil. Tidak ada persitiwa yang luar biasa.

Berdasarkan Tabel 2 dan Tabel 3 juga terlihat bahwa terdapat perbedaan laju inflasi antara RPJMD dan MPS namun perbedaan ini diminimalisasi/trade off dengan laju pertumbuhan ekonomi. Pada RPJMD laju pertumbuhan jauh lebih rendah di bawah laju pertumbuhan ekonomi pada perhitungan dengan pendekatan MPS. Dengan demikian, dapat disimpulkan bahwa jika angka nominal laju inflasi semakin tinggi maka laju pertumbuhan ekonomi juga tinggi, tentu berlaku sebaliknya. Dengan demikian maka informasi yang diperoleh dari hal ini adalah bahwa jika kita mendorong laju pertumbuhan ekonomi maka perlu diantisipasi laju inflasinya. Artinya ada indikasi jika kita akan terus mendorong pertumbuhan ekonomi maka laju inflasi harus dikelola agar laju inflasi tetap optimal sehingga perekonomian berjalan dengan baik dan tetap terkendali dan kondusif.

Kaitan dengan laju inflasi dan pertumbuhan ekonomi hasil penelitian Kardita, Setiawina, dan Budiasa (2018) 
ketimpangan pendapatan masyarakat dipengaruhi secara positif oleh laju inflasi dan pertumbuhan ekonomi. Ini artinya bahwa secara makro laju inflasi suatu daerah sangat penting dan berhubungan secara positif dan nyata terhadap kesejhateraan masyarakat.

Dengan mendasarkan pada laju inflasi dan laju pertumbuhan ekonomi RPJMD dan MPS, maka terdapat perbedaan yang angka nominal. Namun secara angka nominal proyeksinya keduanya relative stabil dan sama. Tidak ada perbedaan yang signifikan antara keduanya. Perbedaan ini hanya terjadi mungkin karena perbedaan pendekatan, perbedaan metodologi penelitian dan ketersediaan data. .

Mendasarkan pada substansi laju inflasi dan laju pertumbuhan ekonomi periode 20202022 sebagaimana telah dipaparakan di atas diperlukan langkah langkankonkrit agar perekonomian Jakarta terkelola dengan baik. Dalam hal ini maka dalam rangka menjaga efek negative dari laju inflasi maka peran Pemerintah Provinsi DKI Jakarta dan TPID Jakarta sangat penting. Hal ini mengingat peran lembaga tersebut terbukti efektif dan efisien dalam pengendalian Inflasi di Jakarta.

\section{Analisis Kebijakan Publik Pengendalian} Inflasi di Jakarta,

politik terhadap permasalahan publik tertentu dan keberlanjutan dari keputusan atau tindakan tersebut berdampak kepada masyarakat (Sanusi dan Putra, 2019). Dengan demikin dalam prosesnya kebijakan publik mengandung arti penelitian untuk mendapatkan data dan informasi, mencari dan mengkaji berbagai alternatif pemecahan masalah atau pencapain tujuan, dan menggunakan pendekatan multidisipilin. Oleh karena itu, bentuk dari kebijakan sangat beragam dari yang formal maupun informal, juga dari yang tampak di permukaan sampai dengan yang tertutup dan rahasia. Dengan dasar ini dalam kontek kajian ini akan memfokuskan pada hasil dari kebijakan pengendalian inflasi yang dilakukan TPID Jakarta.

Selain itu, dalam analisis output hasil analisis kebijakan cukup beragam. Oleh karena itu, agar hasilnya focus maka, output dalam kajian ini memfoksukan pada output kebijakan (studies of policy ouputs) dan saran yang penting untuk perbaikan kebijakan (policy advocacy)

Menurut Howlett dan Ramesh (1995) terdapat llima tahapan dalam penyusunan kebijkan publik. Setiap pengambil keputusan dalam kebijakan public harus memperhatikan tahapan ini. Kelima tahapan tersebut adalah agenda setting, policy formulation, decision making, policy implementation, dan policy evaluation. Masing masing perlu mendapat perhatian khusus agar kebijkan public sesuai dengan tujuan yang telah ditetapkan.

Inflasi merupakan indikator multidimensi. Inflasi dipengaruhi oleh banyak faktor baik faktor yang sifanya teknis ekonomis maupun teknis non ekonomi. Dengan kondisi seperti inilah, dalam pengendalian inflasi harus menggunakan pendekatan yang komprehensif. Artinya dalam konteks penyusunan kebijakan pengendalian inflasi menggunakan pendekatan yang multisector dan multiinstitusi.

Mendiskusikan kebijakan pengendalian inflasi di daerah maka yang paling sentral adalah membahas kinerja Tim Pengendalian Inflasi Daerah (TPID). Di lingkungan Pemerintah Provinsi DKI Jakarta TPID dibentuk melalui Keputusan Gubernur No 2183 TAHUN 2017 tentang Tim Pengendalian Inflasi Daerah. Sesuai dengan Keputusan tersebut bahwa TPID mempunyai tugas: 
a. melakukan pengumpulan data dan informasi perkembangan harga barang kebutuhan pokok dan penting serta jasa di Provinsi Daerah Khusus Ibukota Jakarta;

b.menyusun kebijakan pengendalian inflasi di Provinsi Daerah Khusus Ibukota Jakarta dengan memperhatikan kebijakan pengendalian inflasi Nasional;

c. melakukan upaya untuk memperkuat sistem logistik di Provinsi• Daerah Khusus Ibukota Jakarta;

d.melakukan koordinasi dengan Tim Pengendalian Inflasi Pusat dan Tim Pengendalian Inflasi Daerah Provinsi/Kabupaten/Kota Daerah lainnya; e. melakukan langkah-langkah lainnya dalam rangka penyelesaian hambatan dan permasalahan pengendalian inflasi di Provinsi Daerah Khusus Ibukota Jakarta;

f. melakukan evaluasi terhadap sumbersumber dan potensi tekanan inflasi di Provinsi Daerah Khusus Ibukota Jakarta serta dampaknya terhadap pencapaian sasaran inflasi;

g.melakukan komunikasi publik dalam rangka mensosialisasikan inflasi nasional dan upaya pengendalian inflasi yang telah/ akan dilakukan Tim Pengendalian Inflasi Daerah serta memberikan imbauan (moral suasion) sehingga dapat mengarahkan pembentukan ekspektasi masyarakat; dan

h.menyampaikan informasi kebijakan yang telah dilakukan serta rencana kebijakan oleh instansi-instansi terkait; dan

i. menyampaikan rekomendasi, saran dan pertimbangan yang mendukung pencapaian sasaran inflasi kepada Pemerintah Pusat dan Bank Indonesia.

Dengan tugas yang sangat strategis tersebut, Tim Pengendalian Inflasi Daerah (TPID) Jakarta mengoordinasikan seluruh pemangku kepentingan yang mempunyai peran dalam pengendalian inflasi. Artinya bahwa TPID harus melaksanakan model bisnis penyusunan kebijakan yang pruden dan proper. TPID harus memperhatikan tahapan dengan baik mulai dari agenda setting, policy formulation, decision making, policy implementation, sampai dengan policy evaluation. Hal yang tidak boleh ditinggal dalam hal ini adalah mengomunikasikan berbagai kebijakan pengendalian harga pada lintas instansi Pemerintah Provinsi DKI Jakarta.

Isu yang mencuat dalam rapat Koordinasi Nasional pengendalian inflasi tahun 2019 adalah perlunya perkuatan sinergi kebijakan, peningkatan ketersediaan pasokan dan peningkatan kelancaran distribusi pangan.. Ketiga isu tersebut dapt dikelola dengan baik oleh TPID semestinya. Hal ini mengingat tugas TPID Jakarta sebagaimana di uraikan di atas.

TPID perlu mengkoordinasikan kebijakan yang tidak sejalan antara kebijakan pemerintah pusat dan daerah harus. Jika tidak sejalan maka perlu secepatnya dimitigasi dengan baik. Argumennya adalah bahwa kebijakan yang tidak sejalan akan memberikan efek yang tidak kondusif bagi pelaku usaha.

Selanjutnya dalam hal ketersediaan pangan dan kelancaran distribusi pangan juga menjadi bagian yang terpisahkan dengan tugas TPID Jakarta.

Tugas TPID sebagaimana pada Surat Keputusan Gubernur No No 2183/2017 sudah selaras dan mengkover Program prioritas TPID Jakarta, yaitu program $4 \mathrm{~K}$. Program $4 \mathrm{~K}$, yakni ketersediaan pasokan, kelancaran distribusi, komunikasi dan keterjangkauan harga. Dengan demikian maka yang perlu dan penting adalah implementasi dari program $4 \mathrm{~K}$ tersebut agar inflasi DKI Jakarta dapat sesuai dengan target dan capaian yang direncanakan 
sebagaimana diuraikan RPJMD 2017-2022.. Dengan demikian TPID Jakarta diharapkan berkontribusi nyata dan langung terhadap apa yang diharapkan masyarakat terkait pengendalian inflasi Jakarta sehingga tetap mampu mengoptimalkan daya beli masyarakat dan meningkatkan kesejahteraan, sehingga mendukung pembangunan ekonomi yang berkelanjutan.

Menurut Bank Indonesia (2019) Hasil kerja TPID Jakarta terlihat juga bahwa inflasi ibukota tahun 2018 tetap terkendali dengan realisasi sebesar 3,27 persen (yoy). Selain itu dinyatakan bahwa laju inflasi ibukota sejalan dengan sasaran inflasi nasional tahun 2018 yang ditetapkan sebesar 3,5+/- 1 persen. Hal ini senada dengan hasil penelitian bahwa TPID di Sumatera Utara juga menunjukkan peran yang sangat signifikan terhadap penurunan laju inflasi (Dharma, 2015).

Berdasarkan data empirik, beberapa faktor yang mendukung terkendalinya inflasi Jakarta tahun 2018 diantaranya adalah dengan mengendalikan ekspektasi inflasi masyarakat, tarif transpotrai yang terjaga, dan semkain solidnya program porogram TPID Jakarta dalam menjaga kestabilan harga pangan di Ibukota (BI Perwakilan DKI Jakarta, 2019).

Selanjutnya dikatakan bahwa salah satu faktor yang memengaruhi inflasi di DKI Jakarta terkendali yaitu adanya BUMD yang konsen di bidang pangan. Selaiin itu ditambahkan bahwa optimalisasi peran BUMD pangan dalam pengendalian harga tetap menjadi model bisnis utama TPID Jakarta di ibukota. Oleh karena itu, maka Direktur Utama BUMD klsuter pangan menjadi anggota TPID. Hal ini sebagaimana Keputusan Gubenrur No 2813/2017 tentang TPID bahwa Direktur Utama PD Dharma Jaya, Direktur Utama Perumda Pasar Jaya, dan Direktur Utama PT Food Station
Tjipinang Djaya merupakan anggota TPID Jakarta.

Perlu dipahami juga bahwa BUMD merupkan usaha yang dimiliki pemerintah daerah. Menurut UU No 23 tahun 2014 tentang pemerintahan daerah , bahwa Badan Usaha Milik Daerah adalah badan usaha yang seluruh atau sebagian besar modalnya dimiliki oleh Daerah. Jadi sangat beralasan kalau BUMD harus mempunyai misi pembangunan daerah. Ini selaras dengan tujuan pendirian BUMD sesuai Pasal 331 UU No 23/2014. Pendirian BUMD bertujuan untuk: (a.) memberikan manfaat bagi perkembangan perekonomian Daerah pada umumnya; (b.) menyelenggarakan kemanfaatan umum berupa penyediaan barang dan/atau jasa yang bermutu bagi pemenuhan hajat hidup masyarakat sesuai kondisi, karakteristik dan potensi Daerah yang bersangkutan berdasarkan tata kelola perusahaan yang baik; dan (c.) memperoleh laba dan/atau keuntungan

Dalam rangka pengendalian inflasi, beberapa aksi korporasi yang konstruktif BUMD sangat signifikan. Perumda Pasar Jaya guna mendukung program TPID telah melaksanakan antara lain kerjasama dengan daerah lain dalam memenuhi kebutuhan pasokan bahan pangan untuk DKI Jakarta komoditi pangan dengan Brebes. Komoditi pangan tersebut antara lain pasokan bawang merah. Disamping itu, Perumda Pasar Jaya telah membeli mesin CAS (Controlled Atmosphere Storage) sebagai tempat menyimpan komoditi cabe dan bawang merah yang mampu bertahan hingga 3-6 bulan. Dalam dsitribusi Perumda Pasar Jaya telah membangun Jakgrosir di Pasar Induk Kramat Jati, mini DC rencana di 5 wilayah DKI, Jakmart. Jakgrosir menjual bahan pangan dengan harga grosir yang ditujukan untuk para pedagang yang ada di Pasar Jaya. 
Dalam hal pengendalian inflasi, PT Food Station Tjipinang Jaya juga melakukan aksi korporasi dengan cara bekerja sama dengan daerah produsen beras untuk memenuhi kebutuhan stok beras bagi DKI Jakarta dan menjaga standby stock beras, Sementara PD Dharma Jaya bekerja sama dengan Kabupaten Kupang NTT untuk breeding sapi.

Dalam pelaksanaan koordinasi TPID, upaya pengendalian harga pangan (volatile food) yang menyumbang inflasi cukup besar merupakan program utama, tetapi kelompok administered prices dan kelompok inti juga menjadi perhatian, sebab kebijakan Pemerintah Pusat terkait kebutuhan masyarakat menjadi faktor yang mampu mempengaruhi tingkat inflasi.

Semua kegiatan ini sangat mendukung pelaksanaan pengendalian Inflasi daerah. Dalam hal ini BUMD berarti telah membangun dan memberi sumbangan konstruktif dalam pengendalian inflasi mulai dari sisi supply sampai pada dsitribusi kepada konsumen. Kontrbusi ini sangat membantu dalam menyeimbangkan sisi supply dan sisi demand. Tentu dalam hal ini pada gilirannya akan menstabilkan harga dan dapat mendukung pengendalian inflasi.

Selanjutnya dilakukan pengembangan trading antar pulau; perintisan kegiatan penggemukan dan pembibitan sapi; pengamanan ketersediaan stok bahan baku ternak dan daging dan pengembangan pusat perkulakan; serta revitalisasi terhadap 28 lokasi pasar tradisional; melakukan pemantauan atas kebutuhan dan suplai pangan.

Dalam hal kebijakan inflasi, TPID juga mempunyai fungsi pemantauan dan pengawasan. TPID telah melakukan tugas ini dengan baik terutama dalam hal pemantaaun dan pengawasan pergerakan stok dan pasokan tujuh bahan pangan strategis.
Ketujuh bahan pangan stretgis tersetbu adalah beras, telur ayam, daing ayam, daing sapi, cabai, bawang merah, dan bwang putih. Pergerkan harga ketujuan bahan pangan tersebut terbukti dapat mempengaruhi tingkat inflasi di DKI Jakarta pada tahun yang lalu. Oleh karena itu aktivitas perlu terus dilakukan secara periodik.

Dengan aktivitas TPID yang telah dilakukan tersebut, ternyata telah memberikan hasil yang sukses dan menggembirakan. Sebagaimana disampaikan oleh Bank Indonesia Perwakilan DKI Jakarta bahwa pada umumnya tingkat inflasi bahan makanan DKI Jakarta memiliki tren yang menurun beberapa tahun terakhir ini. Penurunan tingkat inflasi bahan makanan ini dapat disebabkan berbagai faktor tetapi yang paling dominan adalah penurunan dari inflasi bahan makanan terutama bersumber dari tren penurunan subkelompok bumbu-bumbuan (Paparan BI perwakilan , April 2019). Ditambahkan juga bahwa untuk bahan pangan beras dan aneka daging dan hasilnya terjaga stabil. Hal ini mungkin disebsabkan oleh kerja sama pemangku kepentingan yang berkaitan dengan pengelolaan inflasi terjalin dengan baik dan kooperatif. Sehingga memberikan hasil yang sangat bermanfaat dan sumbangan yang konstruktif bagi pembangunan daerah.

Menurut Gubernur Bank Indonesia bahwa dalam pengendlaian inflasi terdapat tiga strategi penting. Pertama adalah sinergi antara pemerintah daerah dan pemerintah pusat dalam mempercepat dan melanjutkan pembangunan infrasturktur pertanian dan pendukngnya. Kedua meningkatkan inovasi program pengendalian inflasi dan ketiga adalah memperluas pemanfaatan teknologi informasi secara terintegrasi. Mendasarkan akan hal tersebut, maka TPID Jakarta telah melakukan ketiga strategi tersebut. Hal ini 
terbukti sangat konstruktif dan efektif dan memberikan hasil yang signifikan.

Keberhasilan TPID Jakarta dalam pengendalian inflasi ini sudah terbukti dan diapresiasi oleh berbagai pihak. Salah satu buktinya adalah bahwa Pemerintah Provinsi DKI Jakarta meraih penghargaan Tim Pengendali Inflasi Daerah (TPID) award 2019 unutk kategori provinsi terbaik pengendali inflasi wilayah Jawa -Bali (Kompas, 25/7/2019). Ini membuktikan bahwa TPID telah berhasil bekerja dengan baik atau dengan kata lain kebijakan pengedalian inflasi DKI Jakarta telah memberikan hasil yang optimal. Secara implicit bahwa karena inflasi terkendali dengan baik maka stabilitas perekonomian DKI Jakarta dapat dikatakan stabil.

Dengan mendasarkan pada hal ini maka hal yang perlu mendapat perhatian dalam pengendalian inflasi adalah perencanaan pengendalian yang tersusun dengan baik, antisipasi dengan menggunakan data yang akurat atas kebutuhan pangan penyumbang inflasi, memastikan pasokan dan supply kebutuhan pangan dengan baik, jalur distribusi diatur dengan baik, komunikaskan semua langkah kepada seluruh stake holder pengendalian inflasi secara proporsional dan professional, berikan penugasan yang jelas dan terarah kepada Badan Usaha Milik Daerah (BUMD). Selain itu, jalinlah kerja sama dengan daerah-daerah lain terutama penyangga pangan Jakarta.

\section{SIMPULAN}

1. Inflasi dalam perekonomian daerah mempunyai peran penting terutama dalam hal stabilitas perekonomian daerah. Unutk itu laju inflasi harus dapat dikelola dengan baik dan efektif, Untuk pengendalian inflasi di daerah, Tim Pengendalian Inflasi Daerah menjadi sangat sentral. Sejalan dengan hal ini maka diperlukan langkah konkrit dalam pengendalian inflasi dari mulai perencanaan, penyusunan target, penyusunan system, pelaksanaan di lapangan, sampai dengan monitoring dan evaluasi.

2. Mengingat bahwa inflasi mempunyai dimensi yang sangat lluas sehingga memerlukan penangnan dari berbagai instansi dan jangka waktu yang Panjang maka dalam hal ini perlu diperhatikan konsistensi kebijakan terutama dalam hal menjaga pasokan dan kelancaran distribusi. Dalam hal ini komunikasi menjadi sangat penting untuk pengendalian inflasi. Menindaklanjuti hal ini maka disarankan juga bahwa pengendalian inflasi dilakukan dengan memperkuat sinergi kebijakan , meningkatkan ketersediaan pasokan dan menaga kelancaran distribusi pangan. Dalam jangka pendek, perlu dilakukan usaha untuk pengamanan pasokan menjelang dan selama hari hrai teretetnu yang diduga akan meningkatkan permintaan.

3. BUMD sebagai badan usaha milik pemerintah daerah sudah selayaknya unutk ambil peran yang konstruktif terutama dalam hal penyediaan beberapa komotiditas pangan utama. Dalam hal ini BUMD harus mampu mengelola Supply bahan pangan pokok yang menyumbang inflasi cukup besar. Dalam hal ini BUMD harus diberikan penugasan dengan arahan yang jelas sehingga mudah untuk mengukur tingkat keberhasilannya.

4. Dengan mendasarkan pada laju inflasi dan laju pertumbuhan ekonomi RPJMD dan MPS, diperoleh bahwa terdapat perbedaan angka nominalnya. Namun 
secara angka nominal proyeksinya keduanya relative stabil dan sama. Tidak ada perbedaan yang signifikan antara keduanya. Perbedaan ini hanya terjadi mungkin karena perbedaan pendekatan, perbedaan metodologi penelitian dan perbedaan data karena keterbatasan keterseidaan data.

5. Kebijakan pengendalian inflasi oleh TPID Jakarta yang salah satunya dengan strategi $4 \mathrm{~K}$, yaitu keterjangkauan harga, ketersediaan pasokan, kelancaran distirbusi dan komunikasi telah memberikan hasil yang sangat baik dan kondusif bagi perekonomian Jakarta. Hal ini ditunjukkan oleh laju pertumbuhan ekonomi Jakarta tahun 2018 pada tingkat yang masih dapat diterima baik oleh dunia usaha, perantara, distributor maupun konsumen. Kesuksesan TPID Jakarta ini juga ditunjukkan oleh diraihnya penghargaan Tim Pengendali Inflasi Daerah (TPID) award 2019 untuk kategori provinsi terbaik pengendali inflasi wilayah Jawa -Bali. Oleh karena itu, disarankan bahwa kebijakan TPID Jakarta dapat ditularkan atau dijadikan model kepada TPID daerah lain .

6. Kerjasama pemerintah Provninsi DKI Jakarta dengan daerah penghasil dan kerja antar BUMD Jakarta dengan daerah lain cukup efektif. .Untuk itu perlu di tingkatkan kualitasnya dan kuantitaisnya agar kelancaran pasokan dapat dikelola dengan baik. Hal ini dimaksudakan untuk mencegah keaniakn yang melebih dari biasanya.

7. Pelaksnaaan Pasar Murah dan Operasi Pasar secara periodeik terbukti efektif dalam pengendalian inflasi untuk itu perlu terus digalakan. Pelaksanaan dikoordinasikan oleh TPID dan waktu dan tempat dan jumlah tempat pelaksanaan harus dipikirkan dengan cermat agar pelaksaaannya efektif.

8. Komunikasi dan sosialisasi terkait kecukupan pasokan dan stabilitas harga, serta komitmen pemerintah untuk hadir di tengah masyarakat sangat penting dan strategis. Ini sangat efektif dalam mempengaruhi perilaku konsumen. Untuk komunikasi dapat dilakukan via televisi, radio, videotron, iklan layanan masyarakat di fasilitas publik dan social media secara massif dan sustain.

\section{DAFTAR PUSTAKA}

Adi, prasetyo arief. (2019). Best Practices : Penguatan BUMD dalam Meningkatkan Pelayanan Publik sesuai Tata Kelola Perusahaan yang Baik, Bahan Paparan, Direktur Utama PT Food Station Tjipinang Djaya.

Akhmad, Dania, 2019. Kausalitas Granger Inflasi dan Pertumbuhan Ekonomi di Kabupaten Magelang. Skripsi Universitas Muhammadiyah Surakarta. Alfirman, Luky (2019). Review dan Prospek Perekonomian Indonesia, Direktur Jenderal Pengelolaan Pembiayaan, disampaikan pada Executive Gathering, 21 Januari 2019, Jakarta.

Asdar, Muh; Wahyudi, Nur Rifqi, Nohong Mursalim (2017). The Influence of Macroeconomic Variables Toward Jakarta Composite Index on Indonesia Stock Exchange. Jurnal Bisnis, Manajemen dan Informatika, JBMI Vol. 14 No. 2 Oktober 2017.

Atmadja. S. Adwin, 1999. Inflasi di Indonesia : Sumber-sumber Penyebab dan Pengendaliannya. Jurnal Akuntansi dan Keuangan Vol. 1, No. 1, Mei 1999 : 54-67 Jurusan Ekonomi Akuntansi, Fakultas Ekonomi - Universitas Kristen Petra 
http://puslit.petra.ac.id/journals/accounti $\mathrm{ng} / 56$

Badan Pusat Statistik, 2016. Provinsi DKI Jakarta Dalam Angka. BPS DKI Jakarta.

Badan Pusat Statistik, 2017. Provinsi DKI Jakarta Dalam Angka. BPS DKI Jakarta.

Badan Pusat Statistik, 2018. Provinsi DKI Jakarta Dalam Angka. BPS DKI Jakarta.

Bank Indonesia, 2019. Kajian Ekonomi dan

Keuangan Regional, Februari 2019. Jakarta.

Dharma, Surya, 2015. Analisis Peranan Tim Pemantuan dan Pengendalian Inflasi Daerah (TPID) terhadap Pengendalian Inflasi di Provinsi Sumatera Utara. Jurnal Ekonomi dan Keuangan Vol.3 No.4.

Dornbusch, R., S. Fischer and R. Startz. 2004. Macroeconomics. Ninth Edition.

The McGraw-Hill Company, New York.

Hidayat, S. 2010. Mengurai Peristiwa Meretas Karsa, Refleksi Satu Dasawarsa Reformasi Desentralisasi dan Otonomi Daerah. Prisma, 29 (3): 4-22.

Kardita, Gede Dirga AA, Setiawina Nyoman Djinar dan Budiasa, I Gede Sujana ( 2018) , Pengaruh Pertumbuhan Ekonomi, Inflasi, DAU, dan Share Ekspor Impor terhadap PDRB terhadap Ketimpangan Pendapatan RumahTangga di Bali. E-Journal Ekonomi dan Bisnis Universitas Udayana 7.7 (2018): 1777-1802. ISSN $2337-3067$

McCann, P. 2006. Urban and Regional Economics. Oxford University Press, New York.

Peraturan Menteri Dalam Negeri Nomor 13 Tahun 2006 tentang Pedoman Pengelolaan Keuangan Daerah.

Peraturan Pemerintah Nomor 58 Tahun 2005 tentang Pengelolaan Keuangan Daerah.
Peraturan Presiden Republik Indonesia Nomor 5 Tahun 2010 tentang Rencana Pembangunan Jangka Menengah Nasional (RPJMN) Tahun 2010 - 2014.

Sanusi, Anwar, dan Putra Fadillah (2019). Analisis Kebijkan Publik NeoInstitusionalisme, Teori dan Praktik. LP3ES. Jakarta

Simanjuntak, R. 2010. Desentralisasi Fiskal dan Manajemen Makroekonomi, Urgensi Suatu Grand Design di Indonesia. Prisma, 29 (3): 35-57.

Sutawijaya, Adrian dan Zulfahmi, 2012. Pengaruh Faktor-Faktor Ekonomi terhadap Inflasi di Indonesia, Fakultas Ekonomi Universitas Terbuka. Jurnal Organisasi dan Manajemen, Volume 8, Nomor 2, September 2012, 85-101

Suparti (2013). Analisis Data Inflasi di Indonesia menggunakan Model Regresi Spline.Media Statistika. Vol 6 No. 1 Juni 2013: 1 - 9 .

Todaro, M. dan Stephen, S.C. 2006. Economic Development, Ninth Edition. Addison Wesley Harlow, Boston.

McConnel, R Campbell and Brue L. Stanley 1993. Macro Economics , Twelfth Edition. McGraw-Hill, Inc.New York.

Howlett, Michael and Ramesh, 1995. M Studying Public Policy. Policy Cycles and Policy Subsystems.Oxford University Press.

Undang-undang Nomor 3 Tahun 2004 tentang Perubahan atas Undang-undang Republik Indonesia Nomor 23 Tahun 1999 Tentang Bank Indonesia

Undang Undang Nomor 25 tahun 2004 tentang Sistem Perencanaan Pembangunan Nasional.

Undang-Undang Nomor 23 Tahun 2014 tentang Pemerintahan Daerah.

Peraturan Daerah No 1 tahun 2018 tentang Rencana Pembangunan Jangka 
Menengah Daerah Provinsi DKI Jakarta 2017- 2022

Undang Undang No 25 tahun 2004 tentang Sistem Perencanaan Pembangunan Nasional

Keputusan Gubernur Nomor 2183 Tahun 2017 tentang Tim Pengendalian Inflasi Daerah

Yurianto, 2018, Jurnal Desentralisasi Fiskla, Ekonomi dan Keuangan Daerah, Defis Edisi 3 Volume III, Mei-Agustus 2018 Proyeksi Potensi Fiskal DKI Jakarta
2018-2022 (Kajian Analisis Model Ekonometrika) Direktorat Jenderal Perimbangan Keuangan Kementerian Keuangan Republik Indonesia

BankIndonesia,2019;https://www.bi.go.id/id/ publikasi/laporantahunan/perekonomian/Pages/LPI_2018. aspx

Kompas,2019.https://megapolitan.kompas.co $\mathrm{m} / \mathrm{read} / 2019 / 07 / 25 / 21184111 /$ pemprovdki-raih-penghargaan-pengendaliinflasi-terbaik-di-jawa-dan-bali 